\title{
Wanted: A Market Definition Paradigm for Monopolization Cases
}

by

Lawrence J. White

EC-99-01 


\title{
WANTED: A MARKET DEFINITION PARADIGM FOR MONOPOLIZATION CASES
}

\author{
Lawrence J. White \\ Stern School of Business \\ New York University
}

\author{
Forthcoming: Computer Industry \\ (The Newsletter of the Computer Industry Committee, \\ American Bar Association Section of Antitrust Law)
}

\begin{abstract}
$\underline{\text { Abstract }}$
For the wide range of antitrust cases involving allegations of monopoly or monopolization (or variations on that theme), the presence of market power is a necessary prerequisite for finding liability. In turn, the definition or delineation of a relevant market is essential for measuring a defendant's market share -- a key determinant of the presence or absence of market power. Unfortunately, there are few or no intellectual underpinnings for the market definition process in monopolization cases. This void contrasts sharply with the substantial conceptual developments of the past two decades with respect to the market definition process in antitrust merger analysis, as embodied in the Merger Guidelines of the U.S. Department of Justice.

This article contrasts the achievements in the merger analysis area with the continuing dilemmas and conundrums in the monopolization area with respect to market definition. In the latter area the "cellophane fallacy" (which is explained), combined with the frequently cloudy state of firmlevel profit data, continues to create confusion as to when the presence of competitors is an indication of the absence of market power and when their presence is the consequence of the exercise of market power. Underlying this confusion is the absence of a clear market definition paradigm for these monopolization cases. Until such a paradigm is developed, the confusion will persist, as will a pattern of erratic and inconsistent outcomes in alleged monopolization cases.
\end{abstract}




\title{
WANTED: A MARKET DEFINITION PARADIGM FOR MONOPOLIZATION CASES
}

\author{
Lawrence J. White ${ }^{1}$
}

\section{$\underline{\text { I. Introduction }}$}

For a wide range of antitrust cases involving outright monopoly or monopolization or variations on the monopolization theme (e.g., predatory behavior, tying, exclusive dealing, and/or other restrictive vertical practices), the presence of market power is a necessary prerequisite for finding liability. In turn, the definition or delineation of a relevant market is essential for the measurement of a defendant's market share -- a key determinant of the presence (or absence) of market power. The U.S. Department of Justice's (DOJ) tying/monopolization case against the Microsoft Corporation, being litigated as this article is written, is a good example of such cases.

Unfortunately, there are few or no intellectual underpinnings for the market definition process in monopolization cases. This void contrasts with the substantial conceptual developments of the past two decades with respect to the market definition process for antitrust merger analysis. In this latter area, although litigants will often differ in their interpretations of the factual record surrounding a disputed merger, a remarkable degree of agreement has emerged with respect to the paradigm that should be used for the analysis. ${ }^{2}$ No such common understanding has been achieved in the

\footnotetext{
${ }^{1}$ Lawrence J. White is the Arthur E. Imperatore Professor of Economics at the Stern School of Business, New York University. During 1982-1983 he was the Director (Chief Economist) of the Economic Policy Office, Antitrust Division, U.S. Department of Justice. This article draws heavily on White (1999a).

${ }^{2}$ For discussions of two prominent merger cases where the litigants disagreed on the interpretations of the facts concerning market definition but agreed on the paradigm for analysis, see White (1994; 1999b) and Dalkir and Warren-Boulton (1999).
} 
monopolization area.

In order to highlight these problems, I will first summarize the market definition paradigm that has developed as the standard framework for merger analysis. I will then contrast the achievements in that area with the ongoing deficiencies in the monopolization area.

\section{The Market Definition Paradigm for Merger Analysis}

The roots of current merger analysis lie in the DOJ's June 1982 Merger Guidelines. Though these Guidelines have since been modified somewhat (in June 1984, June 1992, and April 1997), the essential structure and nature of the Guidelines have persisted.

Since the primary concern of merger enforcement is the prevention of mergers that create or enhance market power, the appropriate or relevant market for merger analysis should generally be the smallest group of sellers that, if they coordinated their actions (e.g., as a consequence of a merger), could successfully (profitably) exercise market power. The usual conceptual test for this potential exercise of market power is the ability of the group of sellers collectively to raise prices by a small but significant amount (from current levels) and to sustain that higher level for a significant period of time. To be successful, this effort at collective exercise of market power would not be thwarted by a sufficient number of buyers switching away to sellers of substitute products or to sellers of the same product located elsewhere. If any particular group of sellers' efforts would be thwarted, then that group cannot constitute a relevant market and the group must be widened until the criterion is satisfied.

In essence, a relevant market (for merger analysis) is one that can be successfully monopolized.

The remainder of the Guidelines proceed to develop the principles that help determine the likelihoods of the post-merger exercise of market power (within the market boundaries that have been 
delineated in accordance with the paradigm just discussed). The major issues raised (along the lines suggested by Stigler [1964]) include: Are the merger partners selling in the same market(s)? What would be the post-merger level of overall seller concentration in each relevant market? What change(s) in seller concentration would occur as a consequence of the merger? How easy is entry? Are there other characteristics of the market -- e.g., the nature of the product, the numbers and types of buyers, the histories and characteristics of the seller -- that would make the post-merger exercise of market power more or less likely? And, in the spirit of Williamson (1968), are there readily identifiable efficiencies that would arise from the merger that would provide a sufficient offset to any perceived likelihoods of the exercise of market power?

As a summary, the Merger Guidelines channel the inquiry in the direction of, "Will this merger, on balance, make things worse?" Since the exercise of market power is a major issue in that inquiry and the sizes of market shares are a major determinant of the likely exercise of market power, providing a paradigm for appropriately defining the boundaries of the market (could market power conceivably be exercised within those boundaries?) is crucial and has been a major achievement of the Guidelines.

\section{Monopolization}

At first glance, it might be tempting to use something similar to the Merger Guidelines' priceincrease paradigm and apply it to monopolization cases to determine whether the defendant possesses market power: Can the defendant profitably raise its prices by a small but significant amount from their current levels? Indeed, this approach is one that is sometimes employed by lawyers and journalists in their descriptions of monopoly power. For example, a leading newspaper's coverage of the Microsoft 
trial included the following statement: "One measure of whether a company holds an illegal monopoly is whether it can raise prices without fear of competition because there is no comparable product available to consumers." (emphasis added) (Brinkley 1999) ${ }^{3}$

This approach is, however, wrong-headed. A core proposition of microeconomics holds that a profit-maximizing monopolist will maintain its price at a level that is higher than the price(s) that would be charged by an otherwise similar group of competitors and in doing so experiences a lower volume of sales than the competitive industry would have experienced. ${ }^{4}$ If the monopolist is already maintaining its price at the profit-maximizing level, then even a small increase from the current level would not be profitable (because the further loss of sales volume would not be sufficiently offset by the higher margins on the remaining sales). ${ }^{5}$ Though a monopolist does have some discretion with respect to pricing (i.e., it can choose any point on the demand curve that it faces), which perfectly competitive firms $^{6}$ do not have, ${ }^{7}$ its profit-maximizing choice is one for which (in the absence of a change in market

\footnotetext{
${ }^{3}$ I have personally heard antitrust lawyers make similar statements.

${ }^{4}$ Its choice of the profit-maximizing price involves a trading-off of the larger profit margins that a higher price would yield against the lower volume of sales that would also be a consequence of the higher price.

${ }^{5}$ Equivalently, if a monopolist could increase its profits through a small price increase from the current price level, then the current level is not maximizing the monopolist's profits -- the firm is "leaving money on the table."

${ }^{6}$ I.e., firms selling identical commodities.

${ }^{7}$ Discretion over price is available to competitive sellers of differentiated products. But, as demonstrated by Chamberlin (1956) in his model of "monopolistic competition," in an industry with differentiated sellers and easy entry, the equilibrium outcome will involve an absence of meaningful market power.
} 
conditions) any higher price would not be as profitable. ${ }^{8}$

Further, since the monopolist maintains its price at a level that implies a loss of sales (to other sellers of something) as compared with the outcome for the competitive industry, the monopolist can always claim, truthfully, that it faces "competition" from other firms and that if it tried to raise its price from current levels it would lose too many sales to those other firms.

As a consequence, any defendant to a monopolization charge can and will always claim that it faces competitors, that these competitors ought to be included in any delineation of a relevant market and consequent computation of market shares, and that the defendant therefore does not possess market power. It is thus important for any analysis of monopolization cases to differentiate between circumstances in which the presence of competitors is the consequence of the exercise of market power (i.e., the maintenance of price above the competitive level) and the circumstances where the presence of competitors is an indicator of the absence of market power. The failure to distinguish between these two sets of circumstances has frequently been termed the "cellophane fallacy," referring to the Supreme Court's decision in U.S. v. E.I.Du Pont de Nemours and Co., 351 U.S. 377 (1956). In that case the DOJ charged that Du Pont had a monopoly of cellophane; Du Pont claimed that the relevant market was "flexible wrapping materials," of which its cellophane sales constituted only a modest share. The Court decided in Du Pont's favor, ignoring information that indicated that it was Du Pont's elevated price for cellophane (which yielded above normal profits) that caused other flexible wrapping materials

\footnotetext{
${ }^{8}$ The only context in which the "raise price" concept could have any analytical content would be a situation in which a competitive market structure is converted into a monopoly (e.g., by merger). Then, starting from the price that the group of competitors had been charging, the newly formed monopolist would want to raise its price (to the profit-maximizing level described in the text). But this concept is quite different from the erroneous one propounded in the newspaper quote in the text above.
} 
to be competitive with cellophane. ${ }^{9}$

A natural supplementary piece of information, to help distinguish between the two sets of circumstances discussed above, would be the profits of the alleged monopolist. But, since the early 1980s, a set of critiques (Benston, 1982; Fisher and McGowan, 1982; Fisher, 1984) have argued that the standard accounting data that are used to report corporate profits are unreliable indicators of true economic profits, casting doubt on this route to the demonstration of market power.

Efforts to demonstrate that an enterprise is exercising market power thus face a quandary: Both a true monopolist and a firm that truly has no market power will be observed to face competitors, and profit data may not be reliable enough to establish the former's excess profits. At the center of this quandary is the absence of a market definition paradigm that could specify market boundaries (and thus permit the identification of market participants and market shares) in a way that would be free of the distortions created by a monopolist's elevated price.

It would seem that a solution to this problem would be to try to specify which (if any) firms would be in competition with an alleged monopolist if the latter sold at prices that reflected only normal (competitive) profits. But this approach runs aground again on the problem of profit measurement.

In some instances, multiple "natural experiments" involving multiple markets with differing degrees of market power may allow a delineation of markets that would be useful in a monopolization context. The recent $\underline{\text { Staples }}^{10}$ case, though it was a horizontal merger case, provides a good example

\footnotetext{
${ }^{9}$ See Stocking and Mueller (1955). For a more recent discussion of a major monopolization case (the DOJ's 1970s prosecution of IBM) that commits the same fallacy with respect to the determination of market power, see Fisher et al. (1983).

${ }^{10}$ F.T.C. v. Staples, 970 F. Supp. 1066.
} 
(Baker, 1998; Dalkir and Warren-Boulton, 1999). In 1997 the Federal Trade Commission (FTC) challenged the proposed merger of Staples and Home Depot. The defendants argued that the merger would not create problems of market power, since (they argued) the relevant product market was all retail sales of office supply products and the two defendants accounted for only a small percentage of such sales. But, the FTC argued, simple price comparisons (as well as more sophisticated econometric analysis) demonstrated that office supply superstores' (OSSs) sales in individual metropolitan areas constituted separate relevant markets: Where Staples or Office Depot was alone in a metropolitan area, its prices tended to be higher than when a second OSS was also selling in the area, and prices were lower still when a third OSS (Office Max) was in the area. Market power could be and was in fact being exercised by OSSs in these metropolitan areas. ${ }^{11}$ Hence, OSSs constituted relevant markets (and the merger would greatly exacerbate seller concentration in these markets). ${ }^{12}$

Though this was a merger case, the same evidence could be used to support a market definition analysis in a hypothetical monopolization case that might be brought against one of the office supply superstore chains (e.g., by a disgruntled supplier). Similar types of analyses might be used in other product or services categories (e.g., airline transportation, some banking services) where markets appear to be local and the local variations in seller concentration or other indicia allow the analyst to observe market boundaries and (in some instances) the exercise of market power within those boundaries.

Where markets are national, however, these natural experiments will not be available, and the

\footnotetext{
${ }^{11}$ For a different view, see Hausman and Leonard (1997).

${ }^{12}$ The Federal District Court judge was convinced, and the FTC won the case.
} 
conundrum described above will persist. A pattern of erratic and inconsistent outcomes in alleged monopolization cases is the inevitable result.

\section{$\underline{\text { IV. Conclusion }}$}

The interconnected problems of determining market boundaries, market shares, and the presence (or absence) of market power in alleged monopolization cases have yet to receive a satisfactory solution. Perhaps the goal of developing a market delineation paradigm for these cases, which would then greatly clarify the remaining tasks, is utopian. But the absence of this paradigm guarantees a concomitantly high level of arbitrariness in the outcomes of alleged monopolization cases.

This is not a satisfactory state of affairs for a major area of antitrust enforcement.

\section{References}

Baker, Jonathan B., "Econometric Analysis in FTC v. Staples," mimeo (1998).

Benston, George J., "Accounting Numbers and Economic Values," Antitrust Bulletin, 27 (Spring 1982), pp. 161-215.

Brinkley, Joel, "Intuit's Chief Urges Division of Microsoft," New York Times, January 5, 1999, p. C2.

Chamberlin, Edward H., The Theory of Monopolistic Competition, 7th edn. Cambridge, Mass: Harvard University Press, 1956.

Dalkir, Serdar and Frederick R. Warren-Boulton, "Prices, Market Definition, and the Effects of Merger: Staples-Office Depot (1997)," in John E. Kwoka, Jr., and Lawrence J. White, eds., $\quad$ The Antitrust Revolution: Economics, Competition, and Policy. New York: Oxford University Press, 1999, pp. 143-164.

Fisher, Franklin M., "The Misuse of Accounting Rates of Return: Reply," American Economic Review, 74 (June 1984), pp. 509-517. 
Fisher, Franklin M. and John J. McGowan, "On the Misuse of Accounting Rates of Return to Infer Monopoly Profits," American Economic Review, 73 (March 1983), pp. 82-97.

Fisher, Franklin M., John J. McGowan, and Joen E. Greenwood, Folded, Spindled, and Mutilated: Economic Analysis and U.S. v. IBM. Cambridge, Mass.: MIT Press, 1983.

Hausman, Jerry A. and Gregory K. Leonard, "Documents versus Econometrics in Staples," mimeo (1997).

Stigler, George J. "A Theory of Oligopoly," Journal of Political Economy, 72 (February 1964), pp. 55-69.

Stocking, George W. and Willard F. Mueller, "The Cellophane Case and the New Competition," American Economic Review, 45 (March 1955), pp. 29-63.

White, Lawrence J., "Application of the Merger Guidelines: The Proposed Merger of Coca-Cola and Dr Pepper," in John E. Kwoka, Jr., and Lawrence J. White, eds., The Antitrust Revolution: The Role of Economics. New York: HarperCollins, 1994, pp. 76-95.

White, Lawrence J., "Present at the Beginning of a New Era for Antitrust: Reflections on 19821983," Review of Industrial Organization, 1999a (forthcoming).

White, Lawrence J., "Economic Analysis in Antitrust Litigation Support: The Federal Trade Commission's 1986 Challenge to the Proposed Merger of Coca-Cola and Dr Pepper," in Daniel Slottje, ed., The Role of the Academic Economist in Litigation Support. Amsterdam: North Holland, 1999b forthcoming.

Williamson, Oliver E., "Economics as an Antitrust Defence: The Welfare Tradeoffs," American Economic Review, 58 (March 1968), pp. 18-36. 